\title{
A SURVEY OF NON-TIMBER FOREST PRODUCTS (NTFPS) IN UPPER MUSTANG
}

\author{
H.B. Chhetri* and V.N.P. Gupta** \\ *Nepal Forest Resources \& Institutions (NFRI), Research Program, Jaulakhel, Lalitpur, Nepal. \\ **Central Department of Botany, Tribhuvan University, Kirtipur, Kathmandu, Nepal.
}

\begin{abstract}
A survey was conducted in Upper Mustang in July 2003 for the documentation of NTFPs using PRA (Participatory Rural Appraisal) and vegetation sampling methods. Altogether 101 species of NTFPs belonging to 36 families and 79 genera were recorded in Upper Mustang (Chhuksang to Lomanthang). A total of 90 species were recorded from the 160 sampling plots in 8 different sampling sites in three major regions Samar, Ghami and Lomanthang of sub alpine and alpine regions. Out of which 61 species were NTFPs and the rest were associated species. In an average 26 species were recorded from each sampling sites out of which an average of 17 species were NTFPs. The index of diversity was higher for NTFPs in comparison to the associated species except in Lomanthang I and Samar I sampling sites. Index of diversity for NTFPs was highest in Samar Lek sampling site followed by Vena, Ghami I, Lomanthang II and Ghami II. The stockings of highly used NTFPs like Thymus linearis and Allium wallichii were high (more than 14 plant $\mathrm{m}^{-2}$ ) whereas the stockings of Calbetia sps., Dactylorhiza hatagirea and Cordyceps sinensis were very low (less than 0.2 plant $\mathrm{m}^{-2}$ ). Sustainable harvesting and management techniques of NTFPs are thought to be of utmost importance in order to conserve and commercialize them.
\end{abstract}

Key words: NTFPs; Sampling plots; Diversity index; PRA; Upper Mustang.

\section{INTRODUCTION}

Upper Mustang an outstanding area in Trans-Himalayan region that lies in the northernmost part of Nepal is rich in bio-diversity. It harbors high altitude desert climate with much of the character of Tibetan plateau and is one of the globally important habitats of the Himalayas. Traditional Tibetan culture in harmony with the mountain eco-system has created a unique ethno-ecological region of Nepal. The massive natural resources have offered unique opportunity to the indigenous people (Gurungs, Sherpas, Bhotes, etc.) of this region for the use of different plants within the local community. Local people have extensive knowledge of the properties and use of plant resources prevalent in the nature.

Non-Timber Forest Products (NTFPs) have been extensively used since long ago when the human life started. NTFPs are most significantly associated with the life of the indigenous ethnic groups who live in inaccessible remote areas. The real reflection of traditional knowledge on forest resources and use of those resources in different aspects can be seen in upper Mustang. Local people use a number of plants for food, spices, fiber, medicine, religious purpose, handicrafts and many other purposes.

These days, NTFPs not only fulfill the need of local people but also provides raw materials for various industries. A thorough overview of the commercial NTFPs have been provided by Edwards (1996). Malla et al. (1997) have prepared identification manual of 116 NTFPs, which have variety of uses. Market for NTFPs as raw materials has increased gradually in recent years due to the growing international market for herbal products in Nepal. Multinational pharmaceutical companies are looking active substances in plants for the cure of various diseases where modern synthetic medicines are perceived to be less effective. Resin and dyes are receiving increasing attention worldwide.

Harvesting of NTFPs can have a positive or negative impact on the conservation of biodiversity (Bhattarai \& Croucher, 1996). However, with the increase in population and associated poverty people are compelled to over harvesting resources for commercial purpose rather than their traditional use. NTFPs are being overused and degraded due to lack of local control over the resources, social and cultural traditions (Shrestha et al., 1998). Nepal's NTFPs base is declining rapidly due to unscientific and unsustainable exploitation of the forest products. In the absence of proper management and control in the collection and trade, NTFPs are becoming vulnerable, endangered and even extinct (Acharya, 2000). NTFP species need to be conserved and managed properly for the sustainable use of resources. Potential NTFPs have important role in the rural subsistence and livelihood. In order to commercialize these species and to maintain the critical population in the long run, there is a need to know the existing volume of the plants in nature, their habitat and distribution. The study aims to explore and document NTFPs with their

Author for Correspondence: Hari Bahadur Chhetri, Nepal Forest Resources \& Institutions (NFRI), Research Program, Jaulakhel, Lalitpur, Nepal. 
status, distribution pattern and population density which helps in developing strategies for commercialization.

\section{METHODOLOGY}

PRA (Participatory Rural Appraisal): Information on NTFPs in different aspects like use, locally growing condition, place of availability, state of collection, use category, marketing, cultivation, etc. were collected in each settlement area by participatory discussion method. Focus Group Discussion and interaction with the key informants and other knowledgeable persons were undertaken. Mostly openended questions were given to them for discussion.

Informal discussions were also undertaken with the village heads, Tibetan doctors (Amchis), priests (Lamas), teachers, village social workers and authorities were also consulted for gathering information on the use and trade of NTFPs. In addition, personal observations were made in the fields to note any noticeable event, which could help to draw conclusions and to develop conservation and management strategies.

Both local people and Amchi were taken to the field to get on site information about the plants. These people were shown the plant species that are ethno botanically important and asked for their knowledge about the plant, local name, use category, use value, ecology and habitats.

Plant Collection and Identification: All plants mentioned in interview and encountered in the field were collected as far as possible and were pressed for use in voucher specimens. The specimens were identified by using relevant literatures and by cross checking with the herbaria of Tribhuvan University Central Herbarium (TUCH), Kirtipur, and National herbarium and Plant Laboratories (KATH), Godavari.

Quantitative Analysis: According to PRA information 8 potential sampling sites (Samar, Vena, Ghami and Lomanthang) were selected within Upper Mustang for the establishment of research plots for ecological survey and identifying the status of NTFPs and other plant species. The study sites represent sub alpine and alpine forest scrubs and meadows where local people generally go for NTFPs collection. Line transects were drawn at the interval of 100 meters and 5 quadrates (each quadrate of $1 \times 1 \mathrm{~m}^{2}$ for herbs and $2 \times 2 \mathrm{~m}^{2}$ for shrubs) were laid at an interval of 20 meters in the line transect. In each sampling sites 4 transects were drawn and a total of 20 quadrates were in those transects. Frequency, relative frequency, density, relative density, and coverage were calculated according to Zobel et al. (1987). However, the diversity index was calculated using Simpson's module (Magurran, 1988)

\section{RESULTS}

General pattern of distribution of NTFPs: NTFPs are found from upper temperate forest of lower altitude to the high altitude sub alpine and alpine pastures and meadows. The study revealed that most of the NTFPs are prevalent in the moist places of sub alpine region. Thymus linearis is common at lower altitude (below 3500m) in open and relatively moist forest and along the trail. Allium wallichii and Arnebia benthamii grow above $3500 \mathrm{~m}$ in upper sub alpine region in relatively dry and open area, where as another species of Allium fasciculatum grows at low altitude area than that of Allium wallichii. Ephedra gerardiana, Potentilla sps., Caragana versicolor and Lonicera rupicola form their forest patches from upper temperate to low alpine in moist and drier places too. Juniperus squamata in association with J. indica form its forest below $3500 \mathrm{~m}$ in east and south facing mountain slopes. However, Betula utilis is prevalent in the north facing slopes in the Juniperus forest at relatively higher altitude. Rheum australe grows in wide range of habitat and was relatively common on moist subalpine meadows. Cortia depressa, Rhododendron lepidotum and Dactylorhiza hatagirea generally grow above tree line in moist habitat. An important medicinal plant Cordyceps sinensis grows at high altitude at around 4000m in alpine meadow. Gentiana robusta, Heracleum candicans and Selenium tenuifolium are common in moist habitat near agricultural lands. Edible mushroom, Calbetia sps. is prevalent in Juniperus forest slopes but is not common. Hippophae tibetana prevalent in relatively less moist slopes in sub alpine region and are distributed mainly in Ghar Gumba area and some areas of Lomanthang (Gurung, 2001). These species are widely used for making juice locally known as 'Tora Juice' in Mustang.

Diversity of Non-Timber Forest Products: Upper Mustang is rich in diverse NTFPs used for various purposes (medicinal, food and spices, aromatic, dyes, construction, religious, etc.), which are generally found in moist areas from low sub alpine to high alpine mountains and in the Trans-Himalayan regions. These plants are used since long before within the community. One hundred and one species of NTFPs have been recorded in Upper Mustang that has been consumed by the local people.

Ninety species were recorded from the 160 sampling plots in eight different sampling sites. Out of these species, 61 species were NTFPs and 29 were associated species. In average 11.13 species were recorded from each sampling site out of which 7.5 species were NTFPs.

Overall, in comparison to the associated species, the index of diversity was highest for NTFPs except in Lomanthang I and Samar I where index of diversity was higher for associated species. This is the reflection of large share of Allium wallichii in the former and Thymus linearis in the later.

Index of diversity was highest in Vena, Samar I and Samar Lek sampling sites and least in Lomanthang I, Ghami I and Samar II sampling sites. The low species diversity in the later sampling sites as compared to the former sites was due to the large share of few species as Allium wallichii, Bistorta macrophylla and grass species but in other sites there is relatively more even proportion of the amount of species. A community that contains a few individuals of many species would have a higher diversity of species than a community containing the same species and the same number of individuals but most of them confined to a few species. The difference in altitude and the aspect of sampling sites have profound influence on species distribution In the present 
Table 1: Total number of species, their individuals and species diversity in different sampling sites.

\begin{tabular}{|c|c|c|c|c|c|c|c|c|c|c|c|c|}
\hline \multirow{2}{*}{ Study sites } & \multicolumn{4}{|c|}{ No. of individuals } & \multicolumn{4}{|c|}{ No. of species } & \multicolumn{4}{|c|}{ Species diversity } \\
\hline & NTFPs & AS & Total & Ratio & NTFPs & AS & Total & Ratio & NTFPs & AS & Total & Ratio \\
\hline Lomanthang I & 609 & 399 & 1008 & 1052 & 13 & 6 & 19 & 2.17 & 2.99 & $3 . .94$ & $6 . .93$ & 0.76 \\
\hline Lomanthang II & 506 & 411 & 917 & 1.23 & 12 & 9 & 21 & 1.33 & 3.63 & 2.7 & 6.33 & 1.34 \\
\hline Ghami I & 621 & 797 & 1418 & 0.78 & 15 & 17 & 32 & 0.88 & 3.89 & 2.79 & 6.88 & 1.39 \\
\hline Ghami II & 960 & 220 & 1180 & 4.36 & 14 & 4 & 18 & 3.5 & 3.59 & 2.36 & 5.95 & 1.52 \\
\hline Vena & 864 & 98 & 962 & 8.32 & 18 & 8 & 26 & 2.25 & 5.6 & 3.13 & 8.73 & 1.79 \\
\hline Samar I & 964 & 220 & 1184 & 4.38 & 19 & 10 & 29 & 1.9 & 4 & 7.94 & 11.94 & 0.5 \\
\hline Samar II & 1582 & 86 & 1668 & 18.4 & 18 & 3 & 21 & 6 & 2.84 & 1.39 & 4.23 & 2.04 \\
\hline Samar Lek & 813 & 618 & 1431 & 1.32 & 27 & 15 & 42 & 1.8 & 8.93 & 6.88 & 15.81 & 1.3 \\
\hline
\end{tabular}

AS=Associated species

study Samar Lek and Vena sampling sites have relatively wet habitat and also Vena lie at comparatively lower altitude than the other sites. (table 1)

\section{Distribution of NTFP in Sampling Sites}

Samar: Samar area is comparatively moist and rich in vegetation than the other regions of Upper Mustang. BirchJuniperus forest is prevalent in this region. Transects were laid in three different sites in this region for the ecological study of NTFPs. Samar I and Samar II were the two sites at relatively low altitude than that of another site Samar Lek. In the first sampling site a total of 29 plant species were recorded out of which 19 were NTFPs, whereas, in the second sampling site a total of 21 plant species were recorded out of which 18 were NTFPs. Thymus linearis, Juniperus indica and Helena elliptica are the important NTFPs found in both of these sites. Thymus linearis was found widely distributed than the others. The third sampling site Samar Lek is the richest sampling site among the 8 sampling sites. A total of 42 plant species were recorded in this site out of which 27 were NTFPs. Calbetia gigantia, Dactylorhiza hatagirea, Rheum australe, Iris sps., Thymus linearis, Juniperus squamata and J. indica are the potential NTFPs recorded in this site. Iris sps. and Rheum australe was found widely distributed than the others.

Vena: This sampling site lies between Syangboche and Samar in the eastern slope. A total of 26 species were recorded in this site out of which 18 were NTFPs. The important tree species Juniperus indica was recorded in $25 \%$ of the sampling quadrates. Other NTFP species Plygonatum cirrhifolium, Asparagus sps. and Stellara chamaejesme were found in considerable number.

Ghami: The study sites lie in the northeastern slope of the Ghami Lek. The first sampling site lies at around $4000 \mathrm{~m}$ in the upper part of Lek. In this site a total of 32 species of NTFPs were encountered out of which 15 were NTFPs. The most important medicinal plant Cordyceps sinensis was found in this site and was reported only in $10 \%$ of the quadrate. Its low frequency may be the reflection excessive illegal collection. The second site with relatively low altitude than the first site harbored a total of 18 plant species out of which 14 were NTFPs. The important NTFPs encountered in this site were Arnebia benthamii, Thymus linearis, Polygonatum cirrhifolium and Allium fasciculatum. Allium fasciculatum and Thymus linearis were recorded in $90 \%$ and $60 \%$ of the quadrates whereas, a important dye yielding plant Arneria sps. was recorded in only $10 \%$ of the quadrates.

Lomanthang: The two potential sampling sites were selected for the ecological study of NTFPs in this region. The study sites lie at Rinjin Fuwa with relatively dry habitat and higher altitude. In the first site a total of 19 plant species were encountered out of which 13 were NTFPs. A total of 21 plant species were recorded in the second site out of which 12 were medicinal. The most important NTFP Allium wallichii that has been traded in Upper Mustang was found in these sites. The species was recorded in $95 \%$ and $65 \%$ of the quadrates in the first and second site respectively. During field visit more than 15 people were found involved for the collection of this species to sell them in the market. Another important NTFP species was Arnebia benthamii with the distribution frequency of $45 \%$ and $35 \%$ in the first and second site respectively. (table 2)

\section{Population Density and Dominance}

The result showed the considerable variation of NTFPs and the associated plant species in the 8 different sampling sites. Overall Density was comparatively higher in Ghami I, Samar II and Samar Lek. The ratio of NFTP to AS was also higher in Samar II but the ratio was lower in Samar Lek and it was even less than 1 in Ghami I. The ratio was highest in Samar II followed by Vena, Samar I, Ghami II, Lomanthaang I, Samar Lek , Lomanthang II and Ghami I. The species importance value has revealed that except in Ghami I NFTP species have shared the total dominance of the community in all other sampling plots.

In Lomanthang I, the dominant NTFP species in terms of IVI value were Allium wallichii, Artemisia sps. and Arnebia benthamii, which contributed about $30 \%$ of the total IVI value of NTFPs. Density of these species were 15.3, 2.65 and 3.7 plant $\mathrm{m}^{-2}$ respectively. In Lomanthang II, Ephedra gerardiana, Lonicera rupicola, Artemisia sps., Allium wallichii and Potentilla fruticosa shared about $38 \%$ of the total importance value of NTFPs with in the community with the density of $1.2,1.15,2.25,11.4,0.4$ plant $\mathrm{m}^{-2}$ respectively.

In Ghami I sampling site, Bistorta macrophylla and 
Table 2: Frequency (\%) NTFPs in eight sampling sites.

\begin{tabular}{|c|c|c|c|c|c|c|c|c|}
\hline Nane of plant species & Lom. I & Lom. II & Ghami I & Ghami II & Vena & Samar I & Samar II & Samar Lek \\
\hline Ajuga lupulina & - & - & - & - & 25 & 60 & 100 & 10 \\
\hline Allium fasciculatum & 10 & 10 & - & 80 & - & - & 80 & - \\
\hline Allium sps. & - & - & -- & - & - & - & - & 10 \\
\hline Allium wallichii & 95 & 65 & - & - & - & - & - & - \\
\hline Anaphalis triplinervis & - & - & 50 & - & - & - & - & - \\
\hline Androsace strigilosa & - & - & 15 & 10 & - & - & 20 & - \\
\hline Anemone rivularis & - & - & - & - & - & - & - & 10 \\
\hline Arisaema flavon & - & - & - & - & 45 & 60 & 40 & 30 \\
\hline Arnebia sps. & 45 & 35 & - & - & - & - & - & - \\
\hline Artemisia gmelinii & - & - & - & - & 60 & - & 40 & - \\
\hline Artemisia santalinifolia & - & - & - & 20 & - & 60 & 20 & 90 \\
\hline Artemisia sps. & 80 & 75 & - & - & 60 & 20 & - & 10 \\
\hline Asparagus fellicinus & 5 & - & - & - & 55 & - & - & - \\
\hline Aster sps. & - & - & 10 & - & 5 & - & - & - \\
\hline Berberis angulosa & 10 & - & - & - & - & - & 60 & - \\
\hline Berberis sps. & - & - & - & 20 & 5 & 80 & - & 30 \\
\hline Bistorta macrophylla & - & - & 70 & - & - & - & 20 & - \\
\hline Calbetia sps. & - & - & - & - & - & - & - & 10 \\
\hline Caragana gerardiana & - & 10 & - & - & - & 20 & - & 20 \\
\hline Caragana versicolor & 5 & - & - & 80 & 15 & - & - & - \\
\hline Clematis vernayi & - & - & - & - & - & 20 & - & - \\
\hline Cordyceps sinensis & - & - & 20 & - & - & - & - & - \\
\hline Cortia depressa & - & 5 & 35 & - & - & - & - & - \\
\hline Cremanthodium arnicoides & - & - & - & - & - & - & - & 70 \\
\hline Dactylorhiza hatagirea & - & - & - & - & - & - & - & 20 \\
\hline Delphinium kumanoense & - & 10 & - & - & - & - & 20 & - \\
\hline Delphinium sps. & - & - & 5 & - & - & - & - & - \\
\hline Dracocephalum heterophyllum & 30 & 15 & - & - & - & - & - & - \\
\hline Ephedra gerardiana & 15 & 40 & 5 & - & - & - & - & 10 \\
\hline Gentiana nubigena & - & - & - & - & 15 & - & - & - \\
\hline Gentiana robusta & - & - & 5 & - & - & - & - & - \\
\hline Halenia elliptica & - & - & - & - & - & 20 & 60 & - \\
\hline Heracleum candicans & - & - & - & - & - & 20 & - & 20 \\
\hline Iris sps. & - & - & - & - & - & - & - & 50 \\
\hline Juniperus indica & - & - & - & 20 & 10 & - & - & - \\
\hline Juniperus squamata & - & - & - & 10 & 25 & 60 & 40 & 30 \\
\hline Lagotis kunawurensis & - & - & 15 & 10 & - & - & - & - \\
\hline Lancea tibetica & - & - & - & 20 & - & - & - & - \\
\hline Lindelofia sps. & 5 & - & - & - & - & 40 & 60 & 40 \\
\hline Lonicera rupicola & 60 & 70 & - & - & - & - & - & - \\
\hline Lonicera spinosa & - & - & - & - & - & 20 & 40 & - \\
\hline Oxyria digyna & - & - & - & - & - & 20 & - & - \\
\hline Pedicularis hoffmeisteri & - & - & 10 & - & - & - & - & - \\
\hline Pedicularis longiflora & - & - & - & - & - & - & - & 70 \\
\hline Pedicularis nodosa & - & 10 & - & - & 10 & - & - & - \\
\hline Plantago himalaica & - & - & - & - & - & - & 20 & - \\
\hline Polygonatum cirrhifolium & - & - & - & 20 & 75 & - & - & 60 \\
\hline Potentilla eriocaspa & - & - & - & - & - & - & 20 & - \\
\hline Potentilla fruticosa & 10 & 25 & - & 50 & 10 & - & - & - \\
\hline Rheum australe & - & - & 15 & - & - & - & - & 80 \\
\hline Rhododendron lepidotum & - & - & 70 & - & - & - & - & - \\
\hline Rosa sericea & - & - & - & - & - & 20 & 20 & - \\
\hline Rumex nepalensis & - & - & - & - & - & 20 & - & - \\
\hline Saussurea graminifolia & - & - & 5 & - & - & - & - & - \\
\hline Selinium tenuifolium & - & - & - & - & 5 & 40 & 20 & 20 \\
\hline Stellara chamaejesme & - & - & 10 & 30 & 15 & - & - & 40 \\
\hline Taraxacum tibetanum & - & - & 25 & - & - & - & - & 10 \\
\hline Thallictrum foliolosum & - & - & - & - & 85 & 40 & 20 & 40 \\
\hline Thymus linearis & - & - & - & 60 & - & 60 & 100 & 10 \\
\hline Unknown sps 1 (Kach) & 5 & - & - & - & - & - & - & - \\
\hline Urtica dioeca & - & - & - & - & - & 40 & - & 60 \\
\hline
\end{tabular}


Table 3: Population density (no. of plant/sq. m) and dominance (IVI) in different sampling sites.

\section{AS=Associated species}

Rhododendron lepidotum shared the highest dominance of the NTFP with the density of 14.45 and 4.5 plant $\mathrm{m}^{-2}$. Other dominant species in terms of IVI were Anaphalis triplinervis, Cortia depressa and Lamiophlomis rotata that shared about $25 \%$ of the total IVI the density of $18.25,13.63$ and 11.66 plant $\mathrm{m}^{-2}$ respectively. In Ghami II sampling site, 2 NTFP plant species Thymus linearis and Allium fasciculatum contributed highest IVI (more than $50 \%$ of the total IVI of NTFP). Densities shared by two species were 18.14 and 16.8 plant $\mathrm{m}^{-2}$ respectively.

In Vena sampling site, Polygonatum cirrhifolium and Artemisia sps. contributed the highest importance value (about 30\%) with the density of 15.75 and 3.9 plant $^{-2}$ respeqtively. Tree species Junipøewsityndica shared 5\% of the community contributing more than $50 \%$ of the total IVI of

as Neopicrorhiza scrophulariiflora, Nardostachys grandiflora and Rheum emodi were not found in the study sites. The low density and even the absence of these potential species may be due to disturbance created by over harvesting and grazing. Also the low germinability of seeds and adverse chilling environment during the long winter season perhaps rendered the dissemination of the species. (table 3)

\section{DISCUSSION AND CONCLUSION}

Upper Mustang is rich in diverse NTFPs, which have potential economic and ethno botanical values. Local people rely on plant resources available in this region for timber, firewood, fodder, medicine, food and raw materials to make handicrafts and tools. Altogether 101 species were found to be ethno botanically importa站. People living within the community

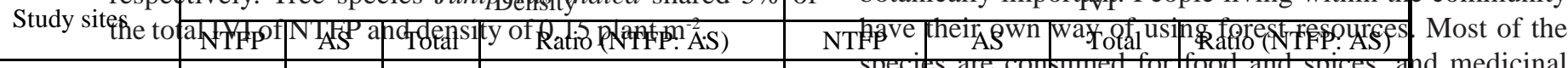

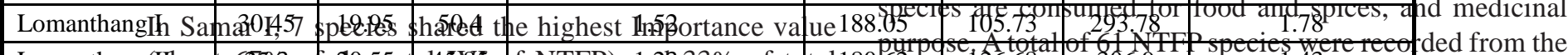

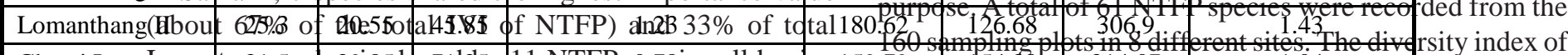

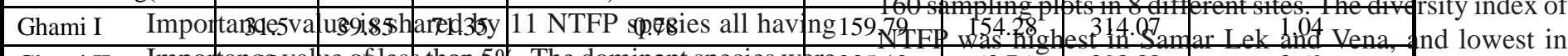

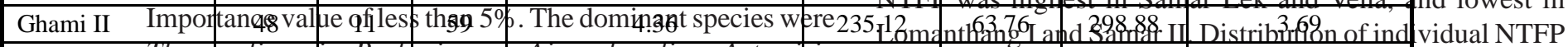

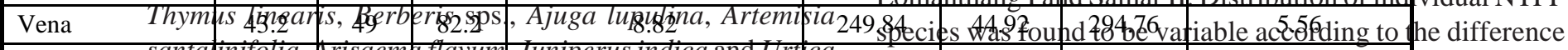

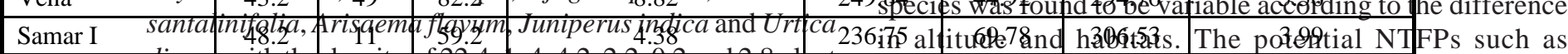

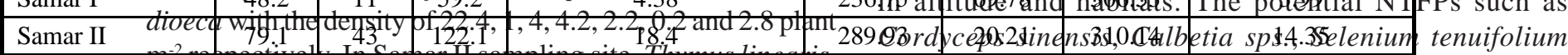

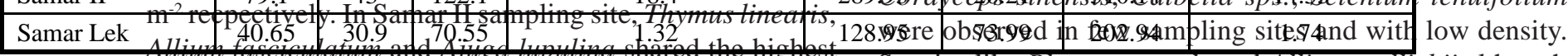
IVI value with in the community with about $53 \%$ of the total IVI value of NTFPs. The densities of these species were 3.6, 23.2 and 5 plants $\mathrm{m}^{-2}$ respectively.

In Samar Lek Iris sps., Artemisia santolinifolia, Rheum australe, Thymus linearis, Polygonatum cirrhifolium and Juniperus indica are the dominant species and contributed about $43 \%$ of the total IVI value of NTFPs. Density of these species were $8.2,0.7,3.8,1.8$ and 0.7 plant $\mathrm{m}^{-2}$ respectively. However, the two potential NTFPs Dactylorhiza hatagirea and Calbetia sps. each shared less than $1 \%$ of the total importance value with the density of 0.2 and 0.1 plant $\mathrm{m}^{-2}$.

The result showed that only few NTFP species have the total dominance in Ghami I \& II in comparison to other sites whereas the potential NTFPs like Cordyceps sinensis, Calbetia sps. and Dactylorhiza hatagirea were observed in only one sampling site with the density of $02,0.1$ and 0.2 plant $\mathrm{m}^{-2}$. Similarly the most important medicinal plants such
Species like Rheum australe and Allium wallichii although found in considerable density but are prevalent in few sampling sites. Disturbance due to over harvesting and lack of awareness on forest resources were observed as the major factors influencing maintenance of NTFPs population.

Although Upper Mustang is suitable habitat for various NTFPs, their trade volume is very low. Only selected species are traded in the local market. Allium wallichii and dust of Juniperus have been traded in thee local market since long ago with relatively same ratio of trade volume. However, Allium wallichii is traded up to Pokhara and other cities. Dried Allium wallichii is sold at the rate of Rs. 300-400/kg and dust of Dhupi is sold at the rate of Rs30-50/kg in the local market. Dust of Dhupi (Dhup) can be commercialized if the marketing channel is available. Seabuckthorn juice is consumed in local market alone and is scarce in the local market too. This is the reflection of low stocking of Seabuckthorn in the forest, which cannot fulfill the market 
need. Cordyceps sinensis, Rheum austarle, Calbetia sps., Neopicrorhiza scrophulariiflora and Rheum emodi are the other species that have high potential value. Cordyceps sinensis is collected and sold illegally by local people at the rate of Rs. 30-50/piece to unauthorized traders. Every year some local people in Ghami collect about 500 pieces of Cordyceps sinensis and sell to the traders who come from outside Mustang.

Rheum australe and Calbetia sps. are consumed at the household level. Very low stocking of Calbetia gigantia is unable to fulfill the demand of local consumption too. People are unaware of sustainable harvesting and management. They just freely collect and use the resources without thinking its use for future days and generations. The species, which has the use of underground part, has the greater chances of extinction from the habitat because of unsustainable harvesting. Even Amchis are unaware of extinction of medicinal plant from their nature for their traditional treatment practice in future generations. Illegal and premature collections of plants are the main threat for the conservation of NTFPs. Sustainable management and harvesting techniques of potential NTFPs is necessary for the commercialization of NTFPs to meet the off-farm employment opportunities for local people.

\section{RECOMMENDATIONS}

Based on the present study following recommendations have been proposed.

- Habitat extension and dissemination of potential species that has increasing demand in the market.

- Create public awareness about conservation and sustainable management of NTFPs.

- Developing nurseries for the dissemination of potential species in suitable natural habitats.

- Provide locals with training to harvest plant resources for use and trade in a sustainable way.

- Create local markets for the NTFPs that can be sold.

- Trade of NTFPs that can be sold in high price and use that income to develop community infrastructure.

- Establish collection depots for NTFPs that can be traded.

- Establish processing center, which reduces the transportation and overhead cost of exporting raw materials.

- Encourage local people to cultivate NTFPs that are highly consumed and can be traded.
- Assess sustainable use, sustainable levels of harvesting and the management practices for the conservation of medicinal plants: perception, utilization, conservation attitude, cultivation methods, etc.

- Provide conservation education to the villagers and in the schools.

\section{ACKNOWLEDGEMENT}

We are thankful to Annapurna Conservation Area Project (ACAP)/Nepal Trust for Nature Conservation for providing financial support to conduct this research. We are very much grateful to the local people of Upper Mustang, for providing information during the field study without which this paper would not have been possible.

\section{REFERENCES}

Acharya, T.P. 2000. Conservation of non-timber forest products (NTFPs) in Humla, Nepal: A case study of Rudikot (Margor) region for Biodiversity conservation. In: Proceedings of the Third Regional Workshop of Community Based NTFP Management, Kathmandu, Nepal. South and East Asian Countries NTFP Network (SEANN). pp. 264-271.

Bhattarai, N.K. and Croucher, J. 1996. Viability of local commercialization of non-timber forest products as a strategy for promoting Biodiversity conservation. In: P.K. Jha, G.P.S. Ghimire, S.B. Karmacharya, S.R. Baral and P. Lacoul (Eds.). Environment and biodiversity in the context of South Asia. Ecological Society, Kathmandu, Nepal. pp. 346-353.

Edwards, D.M. 1996. Non-timber forest products from Nepal: Aspects of the Trade in Medicinal and Aromatic Plants. Forestry Research and Survey, Center Monograph no 1/96. 134 pp.

Gurung, K. 2001. Ecology and Distribution of Seabuckthorn (Hippophae L.) in Mustang District, Nepal. M.Sc. Thesis submitted to Central Department of Botany, T.U., Kirtipur.

Magurran, A.E. 1988. Ecological Diversity and its Measurement. Princeton University Press, Princeton, NJ.

Malla, S.B., Shakya, P.R., Rajbhandari, K.R., Subedi, M.N. and Shrestha, B.L. 1997. Identification manual for some non-timber forestry products of Nepal. FRIS Project paper no. 9. Ministry of Forests and Soil Conservation, forest resource information system Project, Kathmandu, 280 pp.

Shrestha, K.K., Ghimire, S.K., Gurung, T.N., Lama, Y.C. and Thomas, Y.A. 1998. Conservation of Plant Resources, Community Development and Training in Applied Ethnobotany at SheyPhoksundo National Park and it's Bufferzone, Dolpa. World Wildlife Fund, WWF Nepal Program, Report Series No. 33, WWF Nepal.

Zobel, D.B., Jha, P.K., Yarab, U.K.R. and Behan, M.J. 1987. A Manual for Ecology. Ratna Book Distributors, Kathmandu. 